\title{
Erratum to: Alphacoronavirus in urban Molossidae and Phyllostomidae bats, Brazil
}

Karen Miyuki Asano ${ }^{1,2^{*}}$, Aline Santana Hora ${ }^{2}$, Karin Côrrea Scheffer ${ }^{1}$, Willian Oliveira Fahl ${ }^{1}$, Keila lamamoto ${ }^{1}$, Enio Mori ${ }^{1}$ and Paulo Eduardo Brandão ${ }^{2}$

\section{Erratum}

Upon publication, it was noticed that the acknowledgements section of this article [1] should also include: The authors are grateful to Coordenacão de Aperfeiçoamento de Pessoal de Nível Superior (CAPES/PROEX 2327/ 2015) for financial support.

Received: 30 June 2016 Accepted: 30 June 2016

Published online: 07 July 2016

\section{Reference}

1. Asano KM, Hora AS, Scheffer KC, Fahl WO, lamamoto K, Mori E, Brandão PE. Alphacoronavirus in urban Molossidae and Phyllostomidae bats, Brazil. Virol J. 2016;13:110.

* Correspondence: karen.asano@gmail.com

${ }^{1}$ Instituto Pasteur, Av. Paulista, 393, São Paulo, SP CEP:01311-000, Brazil ${ }^{2}$ Departament of Preventive Veterinary Medicine and Animal Health, School of Veterinary Medicine, University of São Paulo, Av. Orlando Marques de Paiva, 87, São Paulo CEP: 05508-270, Brazil
Submit your next manuscript to BioMed Central and we will help you at every step:

- We accept pre-submission inquiries

- Our selector tool helps you to find the most relevant journal

- We provide round the clock customer support

- Convenient online submission

- Thorough peer review

- Inclusion in PubMed and all major indexing services

- Maximum visibility for your research

Submit your manuscript at www.biomedcentral.com/submit 